XXVi VISIT TO THE MUSEUM OF THE ROYAL COLLEGE OF SURGEONS.

These and other so-called wingless birds-their rudimentary wings being useless for flight-probably lost the use of these organs from living where they had no enemies from which to fly, therely escaping the dangers incident to fight; so that those that could not fly would have better chances of living than those that could.

These examples will serve to illustrate the nature of the very pleasant and instructive meeting we had at the College, for which the President proposed a vote of thanks to Prof. Stewart, which was cordially responded to. The party then broke up, but still continued for some time longer to inspect the specimens.

\title{
EASTER EXCURSION.
}

\section{PRELIMINARY EXCURSION TO LYME REGIS.}

April 18 th to 22Nd, 1889.

Director: Honace B. Woodwand, F.G.S., of the Geological Survey of England and Wales.

(Report by The DiRector.)

Hardly any place in the British Isles is richer in features of gcological interest than Lyme Regis; yet, hitherto, the Association had paid it no visit. On two occasions when Excursions had been arranged in the neighbourhcod, the Members had come within a walking distance of the town. Thus, in 1871, under the guidance of Professor Buckman and Mr. Lobley, some Members went from Yeovil to Seaton and examined the cliffs for a short distance enstwards. * Again, in 1885, when your present Director had the honour of conducting a party from Bridport, the Members examined the cliff-sections from Burton Bradstock to Eype, east of Thorncombe Beacon. $\dagger$ The trip now undertaken served to complete the examination of this portion of our coast.

April 18th.-The Members assembled at the Waterloo Station in time for the 2.40 p.m. train on Thurstay, and journeying as far as Axminster, arrived at eight o'clock, about an hour after the appointed time. A break and an omnibus, each with three horses, awaited the party, and as "the shades of night were falling fast,"

* 'Proc. Geol. Assoc.,' Vol. ii, p. 250.

† Ibid., Vol. ix, p. 200. 
an immediate start was made. Proceeding into the little town of Axminster, and beneath an archway throngh the yard of the George Inn, the vehicles were driven at a rapid rate through the narrow street that leads into the Lyme road. It seemed like a revival of oll coaching times, and as the foremost carriage was driven full gallop down the first hill, the Director mildly inquired if no breaks were used in these parts. "Yes, surely," nnswered the driver. "You used no break coming down that hill." "That worn't a hill," was the somewhat gruff reply. Subsequent experience proved there were many far steeper hills, and especially the final deseent to the Three Cups Hotel, which the Members reached safoly soon after nine o'clock.

Lyme Regis lies between two spurs of the straggling Chalk and Upper Greensand outliers that serve to connect the Blackdown Hills of Devonshire with the Dorsetshire Downs. The hills on either side of the town rise to elevations of about 450 or 500 feet, and the valley is drained by the Lim or Lime, from which Lyme Regis derives a part of its name. Dating from about the year 900 , Lyme became a town of some importance in the reign of Heury III., when it was known as Nether-lym supra mare, in distinction from Up-lym (Uplyme). In the reign of Edward I. the manor came to the crown, and as the King's demesne, the town assumed its present name.

In the course of the evening, after a substantial repast, the Director read some notes on the history and geological associations of the neighbomhood, remarking that to George Roberts, justly named "The Historian of Lyme Regis," we are indebted for most of the facts connected with the history of the parish.*

For at least 100 years the fossil treasures of the cliff have been sought after. W. G. Maton, $\dagger$ who travelled through the district in 1794 and 1796, mentions that "All curious productions of this nature are diligently collected by a man living at Charmonth, who is generally known throughout the county by the name of the Curi-man." Roberts informs us that this man sold his ammonites, etc, to the passengers of the coaches. His real name was Lock, though he ras also known as Captain Cury, from his trade in

* See G. Roberts's 'History and Antiquities of the Borongh of Lyme Regis and Charmouth,' 1834, pp. 286, etc.

$f$ 'Observations relative chiefly to the Natural History, etc., of the Western Counties of England,' 2 Vols., 8vo., Salisbury, 1797. See Vol. i pp. 75-76. 
"curiosities." Doubtless, he was one of the earliest fossilcollectors. Others who attained some local notoriety succeeded him, but it is to a lady that geologists aro chiefly indebted for the early discovery of some of the large Saurian remains for which Lyme Regis is famous. Mary Anning, the daughter of Richard Anning, a cabinet-maker at Lyme Regis, was born in 1799 . Her father, who had been also a vendor of fossils, died in 1810, and from that date Mary Anning devoted herself to the collection and sale of these objects. In 1811 she discorered bones of a "crocodile" projecting from one of the leages of lias. Obtaining aif, the remains were exhumed, anil the specimen was afterwards described by Sir Everard Home, under the name Proteo-saurus. One of the original plates illustrating this fossil was exhibited by the Director; but the name Ichthyosaurus (given by Koenig in 1814), having priority, is the name adopted. In 1821 Mary Anning obtained remains of another new Saurian, the Plesiosaurus; and in 1828 she obtained (for the first time in this country) the Pterodactyl, of which the species is now known as Dimorphodon macronyx.* As remarked by De la Beche, this enthusiastic collector exhibited great talent in developing the remains of Saurians. She died in 1847.t

Among the celebrities connected with Lyme Regis, we must not omit the name of Thomas Hawkins. He laboured for some time in collecting the Saurian remains both at Lyme Regis and at Street, near Glastoubury. In 1834 he published a large folio work, entitled 'Memoirs of Ichthyosauri and Plesiosauri, extinct monsters of the Ancient Earth.' $\ddagger$ The illustrations were good, but the names applied to the animals were strange. Thus we have Ichthyosaurus chirostrongulostinus and I, chiroparameteostinus; names that, happily, have not been adopted. Hawkins also published another book, $\S$ which the Members had the opportunity of inspecting at Ronsdon. In this work the same plates were reproduced, but the letter-press is full of fanciful and mystical allusions. Many of his specimens are now in the British Museum, their apparently perfect condition having been prodiced by skilful restoration.

* Conybeare, Buckland, 'Bridgewater Treatise,' Vol, i, p. 203.

+'Phil. Trans,' Vol. civ, p. 571 ; Vol. cvi, p. 318 ; Vol. cviii, p. 24; Vol. cix, pp. 209-212; and Vol. cx, p. 159.

‡ See De la Beche, Address Geol. Soc., 1848.

'The Book of the Great Sea-Dragous, Ichthyosauri and Plesiosauri,' fol., 1840 . 
Mention should also be made of the late J. W. Marder, who was instrumental in obtaining remains of a second species of Pterodactyl, named Pterodactylus Marderi, as well as several new species of Fishes and Crustacea, described by Sir P. Egerton and Dr. H. Woodward.

Trnly science owes much to those who devote themselves to collecting, and yet Lyme Regis never possessed for long a resident geologist who has been loth to part with his or her treasures.

Of others associated with the geology of Lyme Regis, we count several of the old masters-Buckland, Conybeare, and De la Beche.

In one sense Buckland was most intimately connected with the district, for he was born at Axminster, in 1781. His father was Rector of West Chelborough in Dorset, as well as of Templeton and Trusham in Devon. The son, when a child, often visited the Lias quarries near Axminster, collecting fossils which thus early excited his attention.*

Conybeare, who was born in London, in 1787, was appointed Vicar of Axminster in 1836, and held this office until 1845, when he was made Dean of Llandaff.

De la Beche, born also in London, in 1796, resided, when a youtb, for several years at Charmouth and afterwards at Lyme Regis. Buckland first met him at the Assembly Rooms at Lyme Regis. These three geologists were much associated in their work, and while the stratigraphical geology of the district was mainly worked out by De la Beche, the organic remains, and especially the Saurians, were the subject of much study by Conybeare and Buckland, who also contributed a graphic account of the great Landslip.

No wonder "the southern shores of England soon became classic ground for the geological student." $\dagger$ The first maps issued by the Geological Survey, which had been establisued by De la Beche, included the country near Lyme Regis, embraced in Sheets 21 and 22 ; and these were for the most part the work of the founder. The adjoining Sheets 17 and 18 were surveyed by H. W. Bristow, and published in 1850.f

* 'Reliquiæ Diluvianæ,' p. 242 ; "Geology and Mineralogy," ' Bridgewater Treatise,' Ed. 3, 1858.

† 'Obituary notice of De la Beche,' by W. J. Hamilton, Address Geol. Soc., 1856.

$\ddagger$ Re-surveys of the country around Lyme Regis were made in 1873-74, by Clement Reid and H. B. W., but the new editions of the maps have not yet been issued.

VoL, XI, No. 5. 
Of others who have lived and laboured in the neighbourhood of Lyme Regis mention will subsequently be made.

April 19th.-Early on the Friday morning the Members started for Pinhay (or Pinney) Bay, along the footpath beneath Ware Cliffs. In the course of the walk a fine view was seen of the cliffs towards Golden Cap. The most striking feature in the geology here is the unconformable overlap or overstep of the Cretaceons rocks. In the higher grounds at Lyme Regis we see the Chalk and Upper Greensand resting on the Lower Lias; further west they repose on the Rhætic Beds and New Red Marl; while eastwards the Cretaceous rocks overstep in succession the Middle and Upper Lias, and the several divisions of the Oolites.

Proceeding along a tortuous path, amid fallen masses of Chalk and Greensand, and banks decorated with primroses, the Members arrived at the Pinhay ravine, and after a rough and somewhat muddy descent by the watercourse, reached the shore. The ravine itself coincides with a fault that throws down the limestones of the Lower Lias some feet on the west. Eastwards there appears the White Lias, dipping in the same direction, and covered by a thick mass of Blue Lias limestones. The section was described many years ago by De la Beche.* The full thickness of the White Lias is about 25 feet, but the base is not here seen. $\dagger$ The rock is remarkable for containing nrany "pebble-like concretions" which stand out in relief on its weathered faces. These lumps are composed of hard white or pale grey linestone, very similar to the matrix; and the following explanation had been suggested by $\mathrm{Mr}$. A. Geikie, when on a visit to the coast in 1885: the calcareous mud may, during the accumulation of the strata, have been from time to time exposed to the sun's rays, so that films of mud might have curled up, and these, if subsequently rolled by an incoming tide, would be shaped into the lumps which form so conspicuous a feature in the rock.

Fossils are not readily obtained here, but they may be procured from exposures further west, and also in the quarries at Uplyme. The same remarks apply to the succeeding beds of Lower Lias limestone, which represent the "Ostrea-beds," and the zone of Ammonites planorbis. These yield Ostrea liassica, llodiola minima, and Pleuromya crocombeia. The fact is the beds are not very

* See references, p. xxviii supra.

† See Wright, 'Geol. Mag,' 1864, p. 290. 
accessible, and they are not here worked for economic purposes. Moreover, the geologist in examining the cliffs is not free from danger, as pieces of rock occasionally fall, while attention must be paid to the state of the tide both along these "West Cliffs" and in those known as the "Church Cliffs," east of Lyme Regis.

The "Planorbis-beds" are not exposed far eastward of Pinney Bay, for these beds gradually descend to the shore, and do not rise again with the higher beds of limestone aboye the sea-level. The mass of the limestones, or "Blue Lias," which represent also the zones of Ammonites angulatus and $A$. bucklandi, attain altogether a thickness of about 80 feet, undulating a little in the West Cliff, descending to the sea-level below the town, and rising again (excepting the "Planorbis-beds") in the Church Cliffs on the east.

Spines of Urchins (Cidaris and Hemipedina) were noted by Dr. Wright in the clays above the White Lias east of Pinhay Bay, but they were only to be seen on the rocks exposed at low-water during spring-tides.*

Proceeding eastwards higher and higher, beds of limestone came into view, and layers containing Rhynchonella variabilis, Gryphica arcuata (incurva), and one or two specimens of Ammonites angulatus were observed. Further on the stone is extensively worked for the Lime and Cement works, and each layer has its particular name known to the workmen.

Fine specimens of Ammonites charmassei may sometimes be obtained; also Ammonites bucklandi, Nautilus striatus, Lima gigantea, etc.

Lyme Regis is celebrated for its hydraulic cement, but De la Beche remarks that when Smeaton built the Eddystone lighthouse he sent to Aberthaw, in Glamorganshire, for the Lias lime, whereas if geological knowledge had then been available he might have procured it from Dorsetshire. The bands of limestone are employed at the kilns for making "Blue Lias" lime and hydraulic cement, furnishing material for concrete foundations, brickwork, stucco, etc. Much material is also sent away at times in the raw state. Above the main mass of limestones there are also some layers of "Cement-stone," whose composition is naturally best suited for the preparation of cement.

* 'Quart. Jonrn. Geol. Soc.,' Vol. xvi, p. 397. In this paper Dr. Wright did not clearly distinguish the White Lias from the Lower Lias with Ammonites planorbis.

+ 'Report on the Geology of Cornwall,' etc., p. 507. 
On leaving the West Cliff a halt was made at Lyme Cobb for the purpose of lunch. The Cobb itself is said to date from the time of Edward I. as a construction to form a harbour of refuge; but it has many times been damaged or destroyed, and in its present form, although belonging in part to the fourteenth century, the main portion was reconstructed and completed in 1826. This was necessary after a great storm in November, 1824. The damage arose through the tide being checked by a furious gale from the S.S.E., the wind then veered to S. and S.W., and drove the heaped-up waters on to the coast.

The Cobb is built of "Cow-stones" from the Upper Greensand, with a walling of Portland "roach." Its name is said to be involved in mystery, some suggesting that the Cow-stones or cobbles may have originated it. Mr. Klaassen, however, assured us that the name Cob (or Cop) simply meant a point or headland.*

Proceeding along the promenade to the east, and through the town to the Gun Cliff, the Members passed Mrs. Dollin's famous fossil shop, the door of which stood invitingly open. A hurried glance was taken at the many specimens presented to view, and a promise was made to return to this emporium.

The Members now descended to the beach below the Church Cliffs, near the edge of which stands the parish church, whose churchyard has been to some extent curtailed.- Attention was now directed to the great destruction of the cliffs at various points along the coast, caused mainly by gradual crumbling and landslips, while the sea has cleared away the fallen masses. George Roberts mentions that in 30 years, between 1803 and 1834, ninety feet in breadth of the Church Cliffs were lost, while a lane that led to Charmouth has for the most part slipped away to sea. But in this case man has not been free from blame, for Roberts mentions that "thousands of tons of limestone, the very ledges round our shore," have been shipped off, and he feelingly remarks that " a ledge, within a few feet of the eastern jetty, has actually been partly broken up, and the Table-rock and Horse-pond, names familiar to the natives of Lyme, and which bring fond recollections and associations of youth, are no more." $\dagger$

* Isaac Taylor notes Cop (Saxon), a head. 'Words and Places,' Ed. 6, p. 326.

† 'History, eto., of Lyme Regis,' pp. 214, etc. See also "Report on Erosion of Sea-coasts, Axmouth to Eype," by H. B. W., 'Brit. Assoc.' for 1885 . 
Taking advantage of a point that afforded a good general view of the beds exposed in Black Ven, it was remarked that, while the cliff scenery in Yorkshire is grander than that in Dorsetshire, yet our sonth coast has the advantage of presenting the beds in clearer sequence, inter upted only by an occasional fault whose throw can be estimated with little difficulty. No better place probably in Europe exists for the study of the organic remains of the Lias in the successive groups known as "Zones."

The first detailed account of the Lias was given by De la Beche, who, adopting the nomenclature of William Smith and Conybeare, divided the beds as follows*:-

$$
\begin{array}{ll}
\text { Upper Lias Marls } & \ldots\left\{\begin{array}{lll}
\text { Clays with Ammonites } \\
\text { margaritatus, etc. ... } \\
\text { Belemnite Beds, etc. }
\end{array}\right\} \text { Middle Lias (in part). } \\
\text { Lias Limestones... } & \ldots\left\{\begin{array}{lll}
\text { Blue Lias } & \ldots & \ldots \\
\text { White Lias } & \ldots & \ldots
\end{array}\right\} \text { Lower Lias. } \\
\text { Lower Lias Marls } & \ldots\left\{\begin{array}{lll}
\text { Black Shales } & \ldots & \ldots \\
\text { Grey Marls } & \ldots & \ldots
\end{array}\right\} \text { Bhætic Beds. }
\end{array}
$$$$
\text { Modern Grouping. }
$$

The beds now presented to view comprised nearly the whole of the Lower Lias, with the exception of the zone of the Ammonites planorois at the base, and that of $A$. capricornus and $A$. henleyi at the top.

In the Church Cliffs we have only the upper portion of the "Blue Lias" presented to our view. This represents the zone of $A$. angulatus (in part) and that of $A$. bucklandi. Still higher is a bed of shale surmounted by a conspicuous band of hard grey marl, known as the "Table Ledge," which descends to the beach at the foot of Black Ven, and if we include this with the limestones below we have altogether a group about 105 feet in thickness, that represents the zones of $A$. planorbis, $A$. angulatus, $A$. bucklandi, and $A$. turneri. From a stratigraphical point of view this is a fairly convenient division here and elsewhere in the country, for it includes the main mass of the Lower Lias limestones.

The beds above comprise a series of dark and often pyritic shales, with bands of limestone and cement-stone. These beds constitute the dark beds in the lower part of Black Ven, and no doubt gave rise to its name. They attain a thickness of about 190 feet, and include the zones of Ammonites obtusus, $A$. oxynotus, and A. raricostatus.

* 'Trans. Geol. Soc.,' Ser. 2,Vol. ii, pp. 21-30. See also Ser. 2, Vol. i, pp. 40-47, and Plate VIII. 
Still higher there is a well-marked band of pale grey marl, with indurated bands of pale marly limestone, known as the "Belemnite beds," which attain a thickness of about 80 feet. They are well shown not only in Black Ven, but again east of Charmouth, in the cliffs of Stonebarrow and Westhay, where they gradually descend towards the sea-level. A fault in the Charmouth ralley, and another furtlier east, has somewhat shifted their position.

These beds yield Belemnites in abundance, but otherwise are not very fossiliferous except towards the upper part. They represent the zones of Ammonites armatus, A. jamesoni, and A. ibex. At Black Ven, and again at Stonebarrow, we can in places find still higher beds (Green Ammonite beds), but these are better seen in the cliffs of Golden Cap. We have thus in sequence the following divisions of the Lower Lias :-

$$
\begin{array}{lrrrrrr}
\text { Green Ammonite Beds } & \ldots & \ldots & \ldots & \ldots & 105 \\
\text { Belemnite Beds } & \ldots & \ldots & \ldots & \ldots & \ldots & 80 \\
\text { Dark Shales } \ldots & \ldots & \ldots & \ldots & \ldots & \ldots & 190 \\
\text { Limestones and Shales } & \ldots & \ldots & \ldots & \ldots & 105 \\
& & & & & & \\
\end{array}
$$

The leading fossils of these beds are well known through the researches of Dr. Wright, Mr. E. C. H. Day, aided by the local fossil-collectors, Samuel Clark and the late Robert Hunter, of Charmouth. Remains of Saurians occur in the limestones, but more abundantly in the dark shales and cement-stones of Black Ven. About eight species of Ichthyosaurus, seven of Plesiosaurus, two Pterodactyls, and one Deinosaur (Scelidosaurus) have been recorded.* In these beds also were found the Coprolites originally described by Buckland. $\dagger$

Remains of Fishes are also abundant, although their horizons are not so well known. They include species of Acrodus (" fossil leeches"), Hybodus, Eugnathus, Lepidotus, Achmodus, and Pholidophorus, many of which occul in the zone of Ammonites obtusus.

Among Crustacea we tind species of Eryon, Agger, Glyphea, and Scapheus. Echinoderms, Corals, and Polyzoa are not abundant; of the first-named Pentacrinus is found at various horizons, but the most noteworthy form is the Extracrinus briareus, of which

* J. C. Mansell-Plydell, "Fossil Reptiles of Dorset," "Proc. Dorset Nat. Hist. Club,' Vol. ix, p. 1. E. T. Newton, ' Proc. Geol. Assoc.,' Vol. $x$, p. 406. + 'Trane. Geol. Soc., Ser. 2, Vol. iii, p. 223. 
fine examples, generally coated or replaced by pyrites, are found in the zone of $A$. obtusus. From the fact of this organism being often assnciated with lignite, Buckland expressed the opinion that the creatures had attached themselves in large groups to masses of floating wood.*

Of Belemnites and allied forms, we may note the Belemnosepia (or Geoteuthis) described by Buckland in 1836. $\dagger$ Ten years previously he had obtained specimens exhibiting remnants of fossil ink, samples of which were submitted to Sir Francis Chantrey, who had a drawing prepared with the material. The sepia was pronounced to be of excellent quality. Remains of Xiphoteuthis have also been obtained, and Professor Huxley has described two species of Belemnites $-B$. elongatus and $B$. paxillosus - with the ink-bags preserved. $\ddagger$. elongatus was obtained from the zone of Ammonites obtusus.

Among plant-remains, Araucarites and Otopteris have been recorded.

The successive assemblages of organic remains are more marked by the Mollusca, and especially the Ammonites. As a rule the vertical range of the Ammonites is more restricted than that of other forms of life; hence the beds have been divided into zones, of which one characteristic and abundant species is chosen as an index. It must, however, be borne in mind that these divisions are artificial. The index Ammonite may not be found in its zone ; it may range above and below it, while the assemblage of fossils that constitutes the zone is liable to vary in different places, for each species may have a different vertical and geographical range.

Therefore, while there is no doubt that here and there the zones become interblended, yet the general succession of the assemblages of species, and of the relative position of the zonal Ammonites is fairly well marked throughout the country. It may be difficult anywhere to say precisely where one zone ends and another begins, for throughout the Lias the lithological changes are gradual, and in the Lower Lias the "Bucklandi-beds" are not always represented by a thick mass of limestones. In the higher beds we have the marked changes in the Ammonite fauna, without any lithological changes to account for the modification of the forms of life. Nor

* 'Bridgewater Treatise,' 1836, p. 437.

$\dagger$ Ibid., p. 305.

¥ "Monograph on the Belemnitidæ," 'Geol. Survey,' 1864 . 
do we find, as a rule, that the successive species of Ammonites are modifications of those that immediately preceded. The Director suggested that the changes in the assemblages of fossils might have coincided with certain morements of depression which did not affect the character of the sediment deposited, while favouring the incursion of different forms of life.

The Lower Lias limestones, as well as the shales, were mainly sedimentary, being to a large extent mechanically derived from old lands formed of Devonian and Carboniferous rocks. Perhaps a part of Cornwall and Devon, and portions of what is now Wales, may have yielded material, while even Ireland in those days may to some extent have been ground down.

With regard to the Ammonites of the Lias, the Director pointed out that many species figured by Sowerby were originally obtained from Lyme Regis and the neighbourhood. Among these was $A$. bechei (named after De la Beche), A. birchii (after Colonel Birch, a great frequenter of Lyme), A. brookii (after $H$. J. Brooke), A. davoei (after Sir H. Davey), A. henleyi (after H. H. Henley, the Lord of the Manor), and $A$. loscombi (after C. W. Loscombe), A. fimbriatus, A. latcecosta, $A$. stellaris, and $A$. striatus.

One species which had caused some perplexity to Mr. E. T. Newton and himself was A. turneri. The type was obtained from the Drift of Norfolk, and named after Dawson Turner, of Yarmouth. There is some doubt whether this species has actually been obtained at Lyme Regis. A. semicostatus is far more prevalent throughout the country on the horizon marked as that of $A$. turneri, and it occurs at Lyme Regis. Among other forms more or less closely allied are $A$. brookii and $A$. bonnardi.

Examples of all the zonal species were exhibited by the Director, who pointed to the positions of these and other leading fossils in the cliffs, and received unexpected confirmation from a sea-faring spectator, who now and again exclaimed, "That's right," "That's quite right!" The Director remarked that it was desirable to distinguish between zones and fossil-beds. In certain places we have "Gryphæa-beds," "Cardinia-beds," as well as " Fish- and Insect-beds," but these merely indicate the local preservation of certain forms of life.

In the zone of Ammonites obtusus, which lies above the "Table Bed," we find Ammonites brookii, A. birchii, and A. stellaris. Occasionally we find masses of limestone full of small Ammonites 
(A. obtusus and A. planicosta), constituting a kind of Ammonite Marble, like the famous rock of Marston Magna, near Yeovil. Belemnites acutus is occasionally found, but these fossils, so very rare in lower beds, do not come on abundantly until we reach higher stages.

Ammonites oxynotus, and the local variety (A. lymensis) come on above. In the uppermost portion of the dark shales we find the "Metal-bed," with much iron-pyrites, and $A$. raricostatus; also $A$. subplanicosta and $A$. densinodus, specimens of which are cut and polished for brooches. A. armatus likewise is found in the upper portions of this division. We cannot fix precise limits for these zones, but the particular layers in which the species occur may be found with care and patience, especially with the aid of one of the local fossil-collectors.

Iron-pyrites was formerly collected for the manufacture of sulphuric acid. Its decomposition has caused some "spontaneous combustion" in the débris at the foot of the cliffs, and it is on record that in 1751 the cliff's near Charmouth began to smoke, and soon after to burn with a visible flame.

The Members now reached the foot of Black Ven, and having obtained the services of a local guide, they commenced to ascend the cliff. The hill rises to a height of 450 feet in places, and constant slips and changes in the cliffs render guidance advisable; indeed, the path proved to be treacherous in places, and some Members snnk ankle deep in Lias mud. On attaining the level of the Belemnite beds only the more adventurous (including several ladies) clambered up higher to make acquaintance with the Gault, which here rests directly on the Lias.

Fitton first mentioned the occurrence of Gault fossils at this locality, $*$ and in 1865 several species were recorded by the Geological Survey.t To Mr. C. E. De Rance, however, we are indebted for a more particular account of the extension of this formation, and his observations were a few years later supplemented by details furnished by the late Rev. W. Downes.f

At the base of the deposit there is a layer of "grit," noted by

* 'Trans. Geol. Soc.,' Ser. 2, Vol. iv, p. 233.

† T. H. Huxley and R. Etheridge, "Catalogue of Fossils," 'Geol. Survey,' pp. 275, eto.; E. T. Newton, "Catalogne Cretaceous Fossils," Geol. Survey,' 1878.

‡ De Rance, 'Geol. Mag.,' 1874, p. 247 ; Downes, 'Quart. Journ. Geol. Soo.,' Vol. xli, p. 23. 
Mr. Clement Reid in 1874 as about five inches thick, containing small pebbles of quartz, jasper, grit, and eruptive rocks, with fishteeth and derived Lias fossils.* The Gault is from 20 to 25 feet thick, and consists of dark-blue micaceous loam, which merges upwards into the Upper Greensand. Clear sections are rarely to be seen. Among the fossils are Ammonites splendens, Aporrhais orbigniana, Natica gaultina, Cucullaca carinata, Inoceramus concentricus, Lima parallela, Nucula ovata, Panopeea plicata, Pecten orbicularis, etc. As remarked by Mr. Downes, the Gault itself is pervious to such an extent that the springs are thrown out by the Lias clay beneath.

Mr. De Rance noted the occurrence of Gault also at Golden Cap, Stonebarrow, and Pinney Cliff. It appears to thin out east of Sidmouth. The evidence of the fossils tends to show that the Gault of Black Ven is Lower Gault (zone of Ammonites lautus), and that it underlies the "Blackdown beds," which represent the zone of $A$. inflatus.

In other parts of England the Upper Greensand and Gault are intimately connected, gradually replacing one another, so that while in the far west we have only sandy beds that are best termed Upper Greensand, in the east, as at Burham, in Kent, we have only clayey beds that are best termed Gault.

Above the Gault at Black Ven there is from 70 to 80 feet of yellow, grey, and (in places) glauconitic sand, covered by 20 feet or more of broken chert-beds and surface-detritus. The lower portion of these sands contains bands of the indurated sandstone-concretions called "Cow-stones." The origin of the name is not very clear, but Conybeare has suggested that the tumbled blocks that lie scattered on the slopes below the cliffs may have been taken to resemble cattle, much in the same way, I presume, as the Sarsenstones have been likened to grey wethers.

The Greensand is, on the whole, rather destitute of fossils, but about 50 feet nbove the Ganlt Mr. Downes obtained a nest of shells, fragmentary and silicified, like poor Blackdown specimens. Among these were Turritella granulata, Cardium proboscideum, Cucullace glabra, Cyprina cuneata, Pecten quinquecostatus, etc. Teeth of Lamna appendiculata have also been recorded from the neighbourhood. The npper portion of the sands, termed the Fox

* See also R. Etberidge, Ibid., p. 26, and Vol. xxxviii, p. 93 ; and Meger, Vol $\mathrm{xxx}, \mathrm{p}, 370$. 
mould by De la Beche, is exposed in the road between Charmouth and Lyme Regis. The cutting is known as the "Devil's Bellows," because the full fury of the wind is felt there during a storm. Returning by this road (a deviation from the old coach-road), which was made in 1825 , attention was drawn to the great slip by which a portion of the road soon afterwards subsided about 20 feet.

On the return to Lyme Regis a more prolonged visit was made by some of the Members to the store-house of Mrs. Dollin.

April 20th.-On Saturday the Members started by coach and break for Chidcock. Passing through Charmouth, attention was called to the occurrence of Pleistocene Mammalia in the rivergravel of Lyme Regis and Charmouth. Mammoth and Rhinoceros have been recorded.* While in the Axe Valley, at Broom, in the parish of Hawkchurch, above Axminster, palæolithic implements, fashioned out of Greensand chert, were discovered in 1878 by $\mathrm{Mr}$. W. S. M. D'Urban.†

Traces of a "Submerged Forest" have been noted at the mouth of the Char, where the sea has encroached on to the Alluvium. $f$

From Charmouth there was a fine view inland across the Vale of Marshwood, a tract of somewhat cold and stiff Lias Clay bordered by more fertile, lighter lands of Middle Lias and Midford Sands. The vale includes some excellent pasture-land, and yields a good soil for orchards ; hence the Dorset buttel and cider are noted. $\S$

The outliers of the Greensand, of which Golden Cap and the Pillesdon and Lewesdon Pens (909 and 934 feet high) are conspicuous examples, are for the most part uncultivated tracts clothed with gorse or fir-woods, thus contrasting with the fertile knolls nearer Bridport and Beaminster, formed of Midford Sands.

On reaching Chidcock some of the Member's paid a brief visit to the Church, and the party then walked to the sea-shore at Seatown. Tuming their steps eastwards, they proceeded along the base of the cliffs to Down Cliffs, under Thorncombe Beacon. Here is to be seen the finest exposure of the Middle and Upper Lias beds, although the latter are not easy of access.

* De la Beche, 'Report,' p. 412 ; Buckland, 'Reliquiæ Diluvianæ,' p. 174; ; and 'Trans. Geol. Soc.,'Ser. 2, Vol. i, pp. 94, etc.

+ 'Geol. Mag.,' 1878, p. 37. See also J. Evans, 'Journ. Anthrop. Inst.,' Vol. vii, p. 499.

† De la Beche, 'Report,' p. 417 ; and 'Phil. Mag.,' Ser. 2, Vol. vi.

$\S$ L. H. Ruegg, 'Journ. Bath and W. Eng. Soc.,' Vol. viii, p. 180. 
A general view of the cliffs, which at Thorncombe Beacon rise to a height of 509 feet, showed the following succession:-

Feet. In.

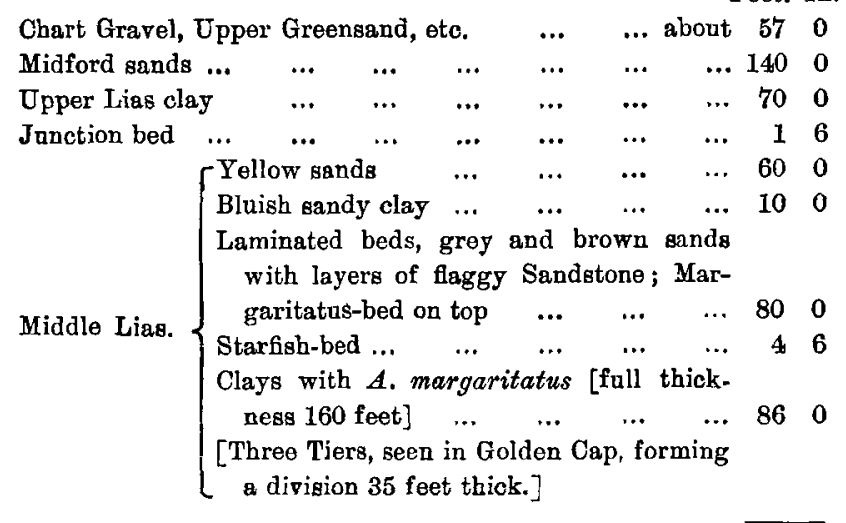

The Midford Sands, locally known as the Bridport and Yeovil Sands, comprise the zones of Ammonites opalinus and A. jurensis. From these beds $A$. insignis, A. variabilis, Rhynchonella cynocephala, etc., have been recorded. They correspond approximately with the "Cephalopoda-bed" and Cotteswold Sands, for, disregarding minor palæontological divisions, we may take these to represent also the zones of $A$. opalinus and $A$. jurensis.*

The Upper Lias clay which merges up into the sandy beds above has not been much worked for fossils, but it may be more readily examined in some places inland, to the north of Bridport. Its basement bed, as observed by Mr. Day, is a hard and compact, pale yellow and pink-coloured limestone, yielding Ammonites bifrons, A. serpentinus, and A. communis ; and this is united with a thin bed of brown and grey ironshot and nodular limestone or Marlstone below (the "Pleurotomaria-bed" of Mr. Day), which yields many Gasteropods, together with Rhynchonella acuta, R. tetrahedra, Terebratula punctata, Belemnites, A. communis, etc. Mr. Beeby Thompson looks upon it as the equivalent of the "Transition bed" of Northamptonshire, which also contains an

* I do not agree with Mr. S. S. Buckman in placing portions of the Cot. teswold Sands in the zone of Ammonitss communis. 'Quart. Jouru. Geol. Soc.', Vol. xlv, p. 469. 
admixture of Middle and Upper Lias fossils. The beds below, consisting of yellow micaceous sands and indurated bands, much resemble the Midford Sands above, and were, indeed, grouped with the Inferior Oolite in De la Beche's first section.*

Most of the fossils obtained from the Middle and Upper Lias of this portion of the coast have been procured from the fallen blocks that lie on the beach ; but these blocks are of marked lithological character, and can be traced after a little investigation to their parent sources. Thus we find, in addition to the Junction-bed of Upper and Middle Lias, blocks of brown sandy limestone yielding Belemnites, Gryphoa cymbium, Pecten aquivalvis, and A. margaritatus, belonging to the "Margaritatus-bed" of Mr. Day, a band that occurs on top of the laminated beds noted in the general section (p. xl).

The most conspicuous blocks are those belonging to the Starfishbed, which has yielded Ophioderma Egertoni and O. tenuibrachiata. The carefully chiselled-out hollows on the smooth under-surfaces of this hard micaceous sandstone indicate the former presence of these organisms, which have been objects of search by fossilcollectors for many years. It is difficult now to procure an example in situ.

Small specimens of Ammonites margaritatus, together with Leda graphica, etc., occur in the blue clays at the base of the cliffs between Seatown and Down Cliff. No Saurians and few Fishes have been recorded from the Middle Lias of this region.

Returning along the shingle to Seatown, a short halt was made for lunch, and the Members then directed their steps westwards towards Golden Cap. The blue clays at the base of the cliff in this direction were seen to belong to a different zone, for a considerable fault occurs in the valley; and instead of Ammonites margaritatus found east of Seatown, the predominant form was Ammonites latcecosta of Sowerby. Portions of this Ammonite are abundant, while more perfect specimens are comparatively rare. Examples are obtained from the nodules of limestone, the chambers being usually filled with calc-spar tinged with a green colour. The specimens when cut and polished are known as "Green Ammonites," and Mr, Day adopted the name "Green Ammonite beds" of the local collectors for this division of the

* 'Trans. Geol. Soc.' Ser. 2, Vol. i, Pl. VIII, A reduced copy of this section accompanies Mr. G. Casley's 'Geology of Lyme Regis.' 
Lias. Associated with this Ammonite we find $A$. loscombi, $A$. fimbriatus, and $A$. davoei, as well as the "Henleyi Ammonites," A. striatus, A. henleyi, and A. bechei. A. latcecosta, as remarked by Oppel, is a Capricorn Ammonite, and the beds may be said to represent the zones of $A$. capricornus and $A$. henleyi. Wright, indeed, regarded $A$. latocosta as the middle age form of $A$. henleyi.

At the base of the Green Ammonite Beds we find a layer of pale grey earthy limestone, yielding Ammonites henleyi, $A$. fimbriatus, etc.

This is the Belemnite Stone of Mr. Day, so called becanse it yields a profusion of Belenunites. These fossils also prevail in the dark shales immediately beneath, and where these beds are exposed on the foreshore at low tide, a little to the south-west of Golden Cap, there is a grand exhibition of Belemnites and other fossils, including $B$. longissimus, $B$. elongatus, $B$. clavatus, $B$. penicillatus, etc., together with Waldheimia numismalis, Plicatulc spinosa, and other forms. These Belemnite Beds no doubt represent the zones of Ammonites jamesoni and A. ibex.*

Golden Cap, 619 feet high, is no doubt the grandest of the Lias cliffs in Dorsetshire. $\dagger$ Its outlines are very varied, the precipices and slopes being scarred by deep channels and chines separated by irregular peaks of Lias clay; while the thick bands of calcareous sandstone, known as the "Three 'Tiers," which rest on the Green Ammonite Beds and constitute the base of the Middle Lias, form great buttresses in places. The Lower Lias clays at the base of the cliff are nuch contorted in places from the effects of great slips.

A long walk over the shingle brought the party to St. Gabriel's Mouth, on the west of Golden Cap, and thence many of the Members made the ascent of the hill and enjoyed the fine prospect it afforded. The bill is capped by a considerable thickness of chert and flint gravel and sands belonging to the Upper Greensand, and on a sunny day these beds appear in marked contrast with the dark Liassic clays beneath ; hence the appropriate name of Golden Cap.

Assembling again at Morecombelake, the Members met their conveyances, and were driven back to Lyme Regis.

* Dr. Wright confessed his inability to define the limits of these zones, Lias Ammonites. 'Palæontograph. Soc.,' p. 68.

+ See Horizontal Section, Geol. Surrey, Sheet 21, by H. W. Bristow. 
April 21st.-On this morning the party divided, some Members driving to Rousdon, while others preferred to walk thither by the footpath along the undercliffs. Those who waiked had a pleasant, though often very rough, path to traverse. They were, however, rewarded by the romantic scenery, and near Charton Bay, below Rousdon, they had the opportunity of seeing the lower portions of the Rhætic Beds, the Grey Marls (35 feet thick), which are exposed resting on the Red Marls; while higher up occur the Black Shales (20 to 30 feet thick), much obscured; and above, the White Lias was to bo seen. A thin representative of the Cotham Marble here occurs. The Black Shales, with Avicula contorta, and the Bone-bed, with Hybodus, Gyrolepis, Saurichthys, etc, are best seen still further west at Culverhole, cast of Axmouth.*

The Members became united again at the Great Landslip of Bindon and Dowlands. An opportunity of visiting this was kindly afforded by Sir Henry Peek, through his son, Mr. Cuthbert E. Peek; and under the guidance of Mr. C. Grover the leading features were examined.

The entire coast-line from Lyme Regis to Axmouth is formed of a remarkable series of cliffs and undercliffs. From one point of view it tells of ruin and devastation, but the results, clothed as they are by Nature, form most picturesque objects. The main cliff is formed of Chalk, with here and there detached pinnacles, as the Chimney Rock under Ware Cliffs, while at a lower level we find the brown crags of the Upper Greensand. The slopes beneatb, based on Lias Clay, Rhatic beds, and Kenper Marl, are strewn with the débris of Chalk and Greensand. Landslips, great and small, have occurred at various places from time immemorial, and the series of cliffs, from which masses have broken away, is named for the most part from adjoining homesteads; thus we have the Ware, Pinhay, Charton, Whitlands, Rousdon (or Rowsedown), Dowlands, Bindon, and Haven Cliffs. One important founder is stated to have occurred in 1765 , when the undercliff at, Whitlands was formed; but the most celebrated one, and, perhaps, the most extensive slip that has occurred during the present century in this country, is that which took place near Bindon and Dowlands in 1839. The summer and autumn months had been extremely wet, and for more than a week previous to the founder cracks had been

* Egerton, 'Proc. Geol. Soc.' Vol. iii, p. 409. 
observed along the brow of the cliffs. The slipping began early on Christmas morning, but the main mass subsided on the following day, when about 20 acres of land broke away, and foundered towards the shore. The result was a chasm from 200 to 400 feet broad, from 130 to 210 feet deep, and about half-a-mile long, in the midst of which smaller broken masses subsided to a lower level than the main landslip. The pressure of the fonndering strata upheaved the sea-bottom adjoining the coast, producing a reef (nearly three-quarters of a mile long and 40 feet high in places), which was at the time covered with marine organisms.

Coastguards spoke of flashing lights and of an intolerable stench, phenomena attributed by Conybeare to the violent attrition of the beds of flint and chert that subsided. The consternation in the neighbourhood was great, many persons attributing the occurrence to an earthquake. Indeed 'A brief account of the Earthquake' was published in London, the writer endeavouring to show that it was prophesied in the 'Revelations.' The inference that an earthquake was the cause is interesting, for there is a record of an earthquake having happened at Lyme in 1689 ; a fact that warns us not to place too great reliance on such records.

The cause of this and other landslips along the coast is due partly to the gentle seaward dip of the Cretaceous strata. At Bindon the Chalk dips $5^{\circ} \mathrm{S}, 2^{\circ}$ E. Moreover, we inave these porous rocks based on a slippery foundation of Lias and other clays. The Lias probably does not extend west of Dowlands, but then we come upon the Rhætic Clays and the Keuper Marls, equally slippery as a foundation.

The lower beds of the Greensand become saturated with water, and springs are thrown out at various intervals. The sand, as Conybeare remarks, would be in a semi-fluid condition, and much of it would be carried away in wet seasons by the springs.* In some cases also the streams erode deep channels in the clays, which channels would be partially filled up with strata from above. Thus the superincumbent rocky beds are undermined, their founda-

* At Rousdon the Members had the opportanity of seeing the fine pictorial work of Conybeare and others. Its title is "Ten plates... representing the changes produced on the coast of East Devon . . . on the 26th December, 1839, and 3rd of February, 1840. From drawings by W. Dawson, the Rev. W. D. Conybeare, and Mrs. Buckland. With Geological Memoir and Sections by the Rev. W. D. Conybeare. The whole revised by Prof. Buckland.' Oblong, London, 1840. See also G. Roberts, 'An Account of and Guide to the Mighty Landslip of Dowlands and Bindon,' Ed. 5, 1840. 
tion gives way, cracks are formed along the clifts, and ultimately large masses fall away or subside.

Although most persons are impressed with the grandeur and beauty of the scene, yet Murray, in his Guide (1859, p. 152), says, "The great chasm will probably disappoint. It too much resembles a gravel-pit!"

In the conrse of the day sections of Greensand and Chalk were to be seen. The beds are exposed by the road leading from Rousdon to the beach, but better opportunities of examining the beds were obtained in the landslip.

The general section of the Greensand may be given as follows :-

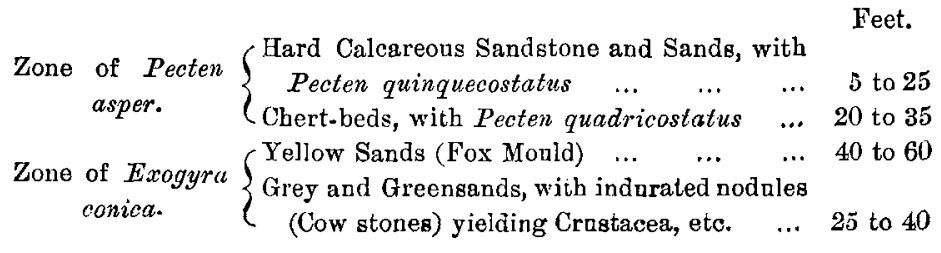

The total thickness of the beds may be estimated at 130 feet, but the character and thickness of each sub-division varies in different places.*

In connection with the chert-beds attention was drawn to Dr. Hinde's researches on the sponge-spicules, which form much of the rock. They are composed of chalcedony, and their canals are infilled with glauconite, while they are imbedded in a matrix of chalcedonic, and sometimes of amorphous, silica.

A good account of the Chalk and Greensand was communicated to the Geological Society in 1825 by De la Beche. $\dagger$ The Chalk includes beds with flints and hard nodules, and at the base a layer with quartz grains, and sometimes a fossiliferons band known as the Chloritic Marl. The thickness in the district is from 150 to 200 feet.

Few fossils have been recorded from the Chalk between Lyme Regis and Axnouth. These include Ptychodus decurrens, Inoceramus, T'erebratula semiglobosa, T'erebratulina gracilis, T. striata.+

At Beer Head (west of Axmouth), of which the Members obtained a distant view, the beds have been worked out in much

* The thickness assigned by De la Beche is excessive. Probably he inclnded the overlying chert detritus, etc. 'Trans. Geol. Soc.,' Ser. 2, Vol. ii, pp. 109, etc. See also C. E. De Rance, 'Geol. Mag.,' 1874, p. 253.

+ 'Phil. Trans.,' 1885, p. 418.

† E. T. Newton, "Cat. Cretaceons Fossils" ('Geol. Survey').

Vol. XI., No. 5. 


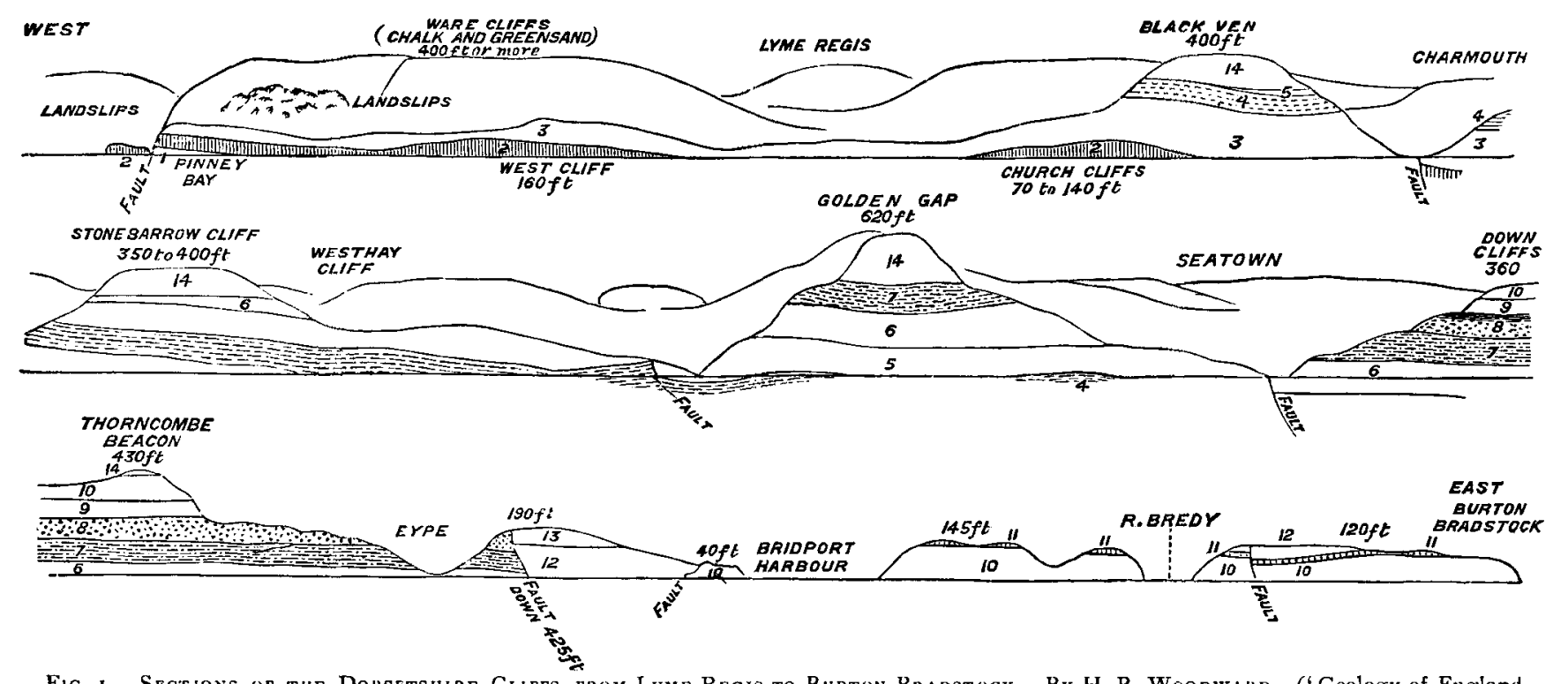

Fig. 1. - Sections of the Dorsetshire Chaff, from Lyme Regis to Burton Bradstock. By H. B. Woodward. ('Geology of England and Wales,' Edit. 2, p. 252.) Horizontal Scale one and a half inches to a mile. Vertical scale much exaggerated.
14. Chert gravel, Upper
13. Forest Marble.
12. Fuller s Earth.
10. Midford Sands.

9. Upper Lias.

8. Sand.

$\left.\begin{array}{l}\text { 8. Laminated Beds. } \\ \text { 6. }\left\{\begin{array}{l}\text { Starfish Bed. } \\ \text { Clay with } \\ \text { margaritatum. } \\ \text { Three Tiers (stone-beds). }\end{array}\right.\end{array}\right\} \begin{gathered}\text { Middle } \\ \text { Lias. }\end{gathered}$

5. Olay (Green Ammonite Beds).

3. Dark clays and shales.

1. White Lias. Rhætic Bed 
detail by Mr. C. J. A. Meyer.* The uppermost layers yield Micraster cor-anguinum, etc. The Beer Stone, much lower down, yields Inoceramns mytiloides. Fitton thought it might represent the Totternhoe Stone, and it is interesting to learn on the authority of $G$. Roberts that a similar bed of hard sandy chalk was formerly dug at Ware, near Lyme Regis. Green grains, quartz grains, and sometimes phosphatic nodules occur in the lower beds of Chalk. The bottom bed yields Ammonites rothomugensis, Scaphites aqualis, Holaster subglobosus, etc. This is the same as the Chloritic Marl of Chard, but while found in other places it has not been observed in its fossiliferous character near Lyme Regis, where the Chalk with quartz grains, three to six feet thick, rests directly on the Greensand, and where, as $\mathrm{Mr}$. Whitalier has remarked, "it is often hard to mark the junction." $†$

It is noteworthy that many of the fossils taken to indicate special horizons in the Chalk in other parts of Englaud have a varying range in the west.

The occurrence of Holaster subglobosus, Ammonites rothomagensis, and Terebratula semiglobosa in the basement-beds of the Chalk in the West of England is significant; and we may fairly speculate on the likelihood of chalky conditions having come on earlier in the east than in the west. Indeed, if we take the case of the Red Chalk at Hunstanton, there is no doubt about the matter.

In connection with this subject it is noteworthy that we have a fairly conformable sequence from Purbeck beds to Chalk in the South-east of England. The same conformable succession from Portlandian beds to Chalk in East Yorkshire has lately been maintained by $\mathbf{M r}$. G. W. Lamplugh. As we proceed westwards, both in the South of England and in Lincolnshire and Yorkshire, there is an overstep of certain members of the Cretaceons systeman overstep marked by upheaval and denudation of the Jurassic rocks in the west. In the South of England this upheaval appears not to have taken place until after the deposition of the Wealden strata, for these beds partake of the general dip that affects the underlying Jurassic strata. Then we have the overstep of the Lower Greensand, as shown in Wiltshire, etc., and, finally, the overstep of Upper Cretaceous strata, which extend beyond the

* 'Quart. Journ. Geol. Soc.,' Vol. xxx, p. 393. A. J. Jukes-Browne 'Geol. Mag.,' 1877, p. 361. Barrois, 'Recherches sur le Terrain Crétacé Superieur de l'Angleterre,' 1876, p. 75.

† 'Quart. Journ. Geol. Soc.', Vol, xxvii, p. 97. See also Fitton, op. cit., 'Trans. Geol. Soc.,' Ser. 2, Vol. iv, p. 234. 
Lower Greensand somewhere to the east of Upway, in Dorset, and again east of Dinton, in the Vale of Wardour.

Attention was drawn to the superficial accumulations that occur on the Cretaceous tracts. The higher grounds of Chalk, and also Greensand, are covered with an irregular bed of Flint and Chert detritus, reminding one of the Clay-with-Alints of Buckinghamshire and Hertfordshire, when that accumulation contains very little clay. Near Lyme Regis and Axminster the bed is mainly formed of broken portions of flint and chert in a clayey or loamy matrix, sometimes nearly $\tilde{\jmath} 0$ feet thick. The bulk of the material is, therefore, local, and sometimes but slightly re-assorted. It is noteworthy, however, that rolled fragments of grit and quartzite and pebbles of quartz, some of large size, are met with. These foreign pebbles were observed by Buckland in 1823, who then observed that they must have been drifted thither before the present valleys were excavated.*

Evidently the bed itself has been to some extent modified during the vicissitudes of the Glacial epoch. $\dagger$ The foreign water-worn materials, in Mr. Ussher's opinion, may have resulted from a redistribution of Tertiary gravels, and he has suggested that the accumulations of chert and flint, if not due directly to ice-action, may date back to the period when the great accumulations of "Head" were formed in many places along our western coasts. +

Doubtless of the same age are the gravel-beds by the Hardy Monument, above Portisham, on the east, and near Newton Abbot on the west.

Returning to Rousdon, the seat of Sir Henry Peek, the Members were conducted over the observatory, which is a Second Order Station of the Royal Meteorological Society. Here observations are regularly made by $M r$. Grover, under the superintendence of Mr. Cuthbert E. Peek, and an annual report is published. The varions instruments were explained by $\mathrm{Mr}$. Grover, and much interest was taken in the evaporation experiments, and also in all arrangement for recording oscillations of the earth's surface. This latter consisted of a solid mass of Beer Stone, 15 feet in length and two feet square, imbedded 10 feet in the earth, on the top of which spirit-levels were placed. These indicated from time to time trifling inclinations east and west.

* 'Reliquiæ Diluvianæ,' p. 247.

† H. B. W., 'Geol. Mag.,' 1874, p. 335.

† 'Quart. Journ. Geol. Soc.,' Vol, xxxiv, pp. 449-458. See also Do Rance, 'Geol, Mag.,' 1874, p. 247. 
A hearty vote of thanks was accorded to $\mathrm{Mr}$. Grover, and also to Sir H. Peek and Mr. C. E. Peek for their courtesy in permitting the Members to examine the Landslip on a day when the public are usually excluded.

A pril 22nd.-On Easter Monday the Members took leave of Lyme Regis, and, after being driven to Bridport, took train to Upway Station, where they were met by Mr. Hudleston, who now took the direction of the party.

\section{REFERENCES.}

Geol. Survey Map, Sheets 22 and 17; and Horizontal Sections, Sheet 21.

DAY, E. C. H.-.- "On the Middle and Upper Lias of the Dorsetshire Coast." 'Quart. Journ. Geol. Soc.,' Vol. xix, pp. 278.297.

Wright, Dr. T._-"The White Lias of Dorsetshire." 'Geol. Mag.,' Vol. i, 1864, pp. 290-292.

Wright, Dr. T.- "On the Zone of Avicula contorta, and the Lower Lias of the Sonth of England." 'Quart. Journ. Geol. Soc.,' Vol. xvi, pp. 374. 411 ; and "Lias A mmonites" (" Palæontograph. Soc.').

Downes, Rev W._-"The Cretaceous Beds at Black Ven, near Lyme Regis." 'Quart. Journ. Geol. Soc.', Vol. xli, pp. 23-26.

Roberts, George.- An Account of the Mighty Landslip at Dowlands and Bindon, near Lyme Regis, December 25, 1839.' 8vo. Lyme, 1840.

Woopward, H. B.- 'Geology of England and Wales.' Ed. 2, 1887, pp. $262-264,271,272,391,418$, and 598.

\section{EASTER EXCURSION, 1889.}

\section{EXCURSTON TO WEYMOUTH.}

Easter Monday and Tuesday, Aprit 22Nd and 23 rd.

Director: W. H. Hudlestron, F.R.S., Sec.G.S.

$$
\text { (Report by 'l'HE DiRecror.) }
$$

April 22nd, Easter Monday.-The principal portion of the party, viz., that from Lyme Regis, reached Upway Station about 11.30 a.m. Contingents from London and Bath joined subsequently. A move was made in the direction of Elwell, at the foot of the Ridgway Rise. The Director had to announce that the clay-pit in the railway-cutting at the foot of the hill had been closed since the last visit of the Association ten years ago. Moreover, there had been very little fresh working in the stonequarries on the hill lately. The lower division of Portland Stone, known as the chalky or flinty series, has been here quarried for lime, but there is no section showing the actual base. A 